African Journal of Biomedical Research, Vol. 8 (2005); 163 -168

ISSN 1119 - 5096 (C) Ibadan Biomedical Communications Group

Available online at http://www.bioline.org.br/md

Full Length Research Article

\title{
Distribution Pattern of Enteric Organisms in the Lagos Lagoon, Nigeria
}

\author{
${ }^{* 1}$ Ajayi A.O. and Akonai K.A. ${ }^{2}$ \\ ${ }^{1}$ Department of Microbiology, Adekunle Ajasin University, P..M.B. 01, Akungba - Akoko, Ondo \\ State, Nigeria. \\ ${ }^{2}$ Department of Microbiology, Obafemi Awolowo University, lle- Ife, Osun State, Nigeria.
}

Received: December, 2004

Accepted: August, 2005

\begin{abstract}
A wide range of organisms was encountered in the 24 sampled sites of the Lagos Lagoon. The enteric gram-negative shortrods, Lactose fermenting organisms such as Klebsiella spp, Enterobacter spp and Escherichia coli were prevalent in most of the Lagoon sites studied. The in vitro antibiotic sensitivity profile of the isolates revealed that high proportion of the bacteria isolate showed multiple antibiotic resistance. This is epidemiologically significant in the event of human infections. Since these organisms are widely distributed in the surface water they are likely to contaminate marine organisms which if consumed by people in the area may result in disease spread which could also be complicated by the antibiotic resistant nature of the organisms involved.
\end{abstract}

Key words: Distribution, Enteric, Lagoon, Lagos, Organisms, Pattern

\section{INTRODUCTION}

The Lagos Lagoon is a great expance of bw lying salt and brackish water covering an area of about $208 \mathrm{~km}^{2}$. In most places the Lagoon is usually less than 1.5 meters deep (Akpata and Ekundayo, 1978). The total range is small, 0.3-1.3 meters. The interconnecting creeks are very shallow. They are sites of active sedimentation and deposition of mud (Ajao and Fagade 1990).

The increase in population and industrialization of the city of Lagos which is a commercial nerve center of this country, Nigeria, has resulted into proportional generation of various types of wastes or contaminants into the Lagoon. The contaminants and the diverse nature of the marine Lagoon environment result in succession of various species of microorganisms which may be potential sources of health hazard. The discharge of raw sewage into the Lagoon has important health implication (Akpata \& Ekundaayo, 1978; Halasi-Kun, 1981). The occurrence of the enteric organisms and other microorganisms in the
Lagos Lagoon may lead to contamination of aquatic life and other food products, thereby causing possible health hazard to those products. In the food chain consumption of hazardous wastes or infectious agents can adversely affect the consumers and organisms of the high trophic level (Prescott et al., 2002).

The infiltrations of various forms of contaminants into the Lagoon necessitate the routine monitoring of this coastal water body. In order to appreciate the level of pollution and environmental degradation of the area, an environmental impact assessment (E.I.A) study of the area should be carried out. Munn (1979), identified E.I.A as an activity designed to identified and predict the impact of project on the biogeophysical programmes, operational procedures and to interprete and finally communicate the impact. The conservation of the biogeophysical component of the ecosystem is desirable for man's co-existence, hence the need to monitor it's dynamics. 
Microorganisms like other life forms are, an integral and important components of the ecosystem (Prescott et. al., 2002). There is a wide variety of microorganisms in nature and they are versatile in the use of diverse nutrients in the environment. The specificity for nutrients or succession of certain organisms in an environment may serve as bioindicators of the presence of pollutants in such an environment (Baker, 1976). This study will help to determine some polluted zones of the Lagos Lagoon based on the presence of specific enteric organisms in certain areas of the study site. The occurrence of such organisms are potential threat to the ecological area, thus possible health remedy can be made from the study for sustainable economic development.

\section{MATERIALS AND METHODS}

\section{Sampling Technique}

Twenty-four stations were mapped out on the Lagos Lagoon for the month of February and June study periods. The Nigerian Institute for Oceanography and Marine Research (NIOMR) assisted in the research with the aid of NIOMR field assistants that routinely used the designated map to locate sampling points from where water samples were collected for analysis (Fig. 1).

Surface water was collected within a depth of one foot into sterile plastic container employing a Ruthner standard water sampler, $(8 \mathrm{~cm}$ diameter and $50 \mathrm{~cm}$ long, capacity $500 \mathrm{ml}$ ). Approximately about a litre of water was collected from each sampling point. The samples were labelled and sealed, and immediately kept in a cooler containing ice on board the boat for preservation. The water samples were analyzed within 36 hours of sample collection. The coliform counts were determined employing Millipore membrane filters (Satorious, $\mathrm{GmbH}$ ). On incubation of the serially diluted sampled water in Nutrient agar plates at $37^{\circ} \mathrm{C}$ overnight, the organisms were counted by enumerating the colony forming units of the sample sources cultured.

\section{Identification and antibiotic sensitivity pattern of isolates}

Each bacterial isolates was identified based on their morphological characteristics, colour, arrangement of vegetative cell and possession of spores and other biochemical characteristics (Robert et al., 1984), The in vitro antibiotic susceptibility testing of bacterial isolates was performed using the standardized disc agar diffusion method described by Bauer et al (1966). Paper disc medium (PDM), Antibiotic sensitivity agar (AB BIODISK, Solna, Sweden) was the plating medium used. The antibiotic discs (AB BIODISK, Solna, Sweden) that were placed on the culture medium and used for this test included Gentamicin, Nalidixic acid, Tetracycline, Spectinomycin, chloramphenicol and streptomycin with $30 \mu \mathrm{g} / \mathrm{disc}$ each in quantity. Others were Trimethoprim sulfamethoxazole $1-2+23.8 \mu \mathrm{g} / \mathrm{disc}$

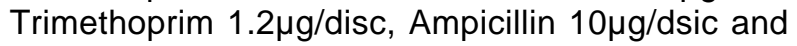
sufamethoxazole $23.8 \mu \mathrm{g} / \mathrm{disc}$.

\section{RESULTS}

Various species of microorganisms encountered in the Lagos Lagoon were identified by standard microbiological techniques as shown in Table 1. The occurrence of microbial species encountered in different designated sampling sites of the Lagoon was also studied (Table 2).

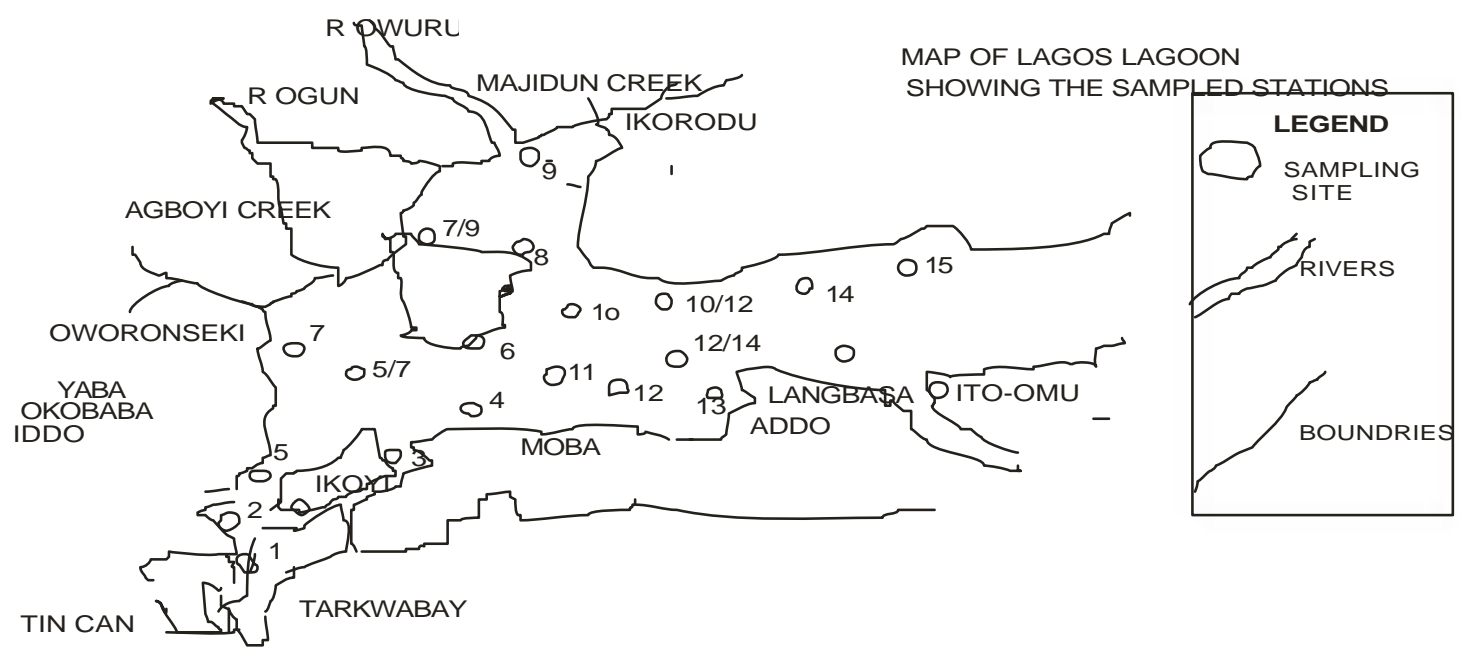

Fig. 1: Map of Lagos Lagoon 
Table 1:

Morphological and Cultural Characteristics of Bacteria Isolates From The Lagoon

\begin{tabular}{|c|c|c|c|c|c|c|c|c|c|c|c|c|c|c|c|c|c|c|}
\hline $\begin{array}{l}\text { Isolate } \\
\text { Code }\end{array}$ & $\begin{array}{l}\text { Cultural } \\
\text { characteristics } \\
\text { and pigments } \\
\text { on solid media } \\
\end{array}$ & Shape & $\begin{array}{l}\text { Gram } \\
\text { Stain }\end{array}$ & $\begin{array}{l}\text { Blood } \\
\text { Heamolysi } \\
\mathrm{s}\end{array}$ & Catalase & $\begin{array}{l}\text { O-F } \\
\text { Glucos } \\
\text { e }\end{array}$ & $\begin{array}{l}\text { Nitrate } \\
\text { Reduction }\end{array}$ & $\begin{array}{l}\text { Mannito } \\
1\end{array}$ & $\begin{array}{l}\text { Glucos } \\
\text { e }\end{array}$ & $\begin{array}{l}\text { Fructos } \\
e^{-1}\end{array}$ & $\begin{array}{l}\text { Lac- } \\
\text { tose }\end{array}$ & $\begin{array}{l}\text { Suc- } \\
\text { rose }\end{array}$ & $\begin{array}{l}\text { Raffi- } \\
\text { nose }\end{array}$ & $\begin{array}{l}\text { Arabi- } \\
\text { nose }\end{array}$ & $\begin{array}{l}\text { Citrate } \\
\text { utiliza- } \\
\text { tion }\end{array}$ & $\begin{array}{l}\text { EMB Agar } \\
\text { (Lactose } \\
\text { Formation } \\
\end{array}$ & $\begin{array}{l}\text { Mannitol } \\
\text { Salt Agar }\end{array}$ & Identification \\
\hline 1 & $\begin{array}{l}\text { Lobate,raised, } \\
\text { yellow, } \\
\text { Colony. }\end{array}$ & Rod & & $\begin{array}{l}\text { B- Heam- } \\
\text { olysis }\end{array}$ & + & $\mathrm{O} / \mathrm{F}$ & + & +9 & $+g$ & + & + & & - & & - & $\begin{array}{l}\text { Green } \\
\text { metallic } \\
\text { sheen }\end{array}$ & ND & $\begin{array}{l}\text { Escherichia } \\
\text { coli }\end{array}$ \\
\hline $1 \mathrm{~b}$ & $\begin{array}{l}\text { Undulate, } \\
\text { rough,raised,yello } \\
\text { w } \\
\text { Colony }\end{array}$ & $\begin{array}{l}\text { Cocci } \\
\text { in } \\
\text { chain }\end{array}$ & + & $\begin{array}{l}\text { a- Heam- } \\
\text { olysis }\end{array}$ & - & $\mathrm{O} / \mathrm{F}$ & + & +9 & + & $+g$ & $+g$ & +9 & $+g$ & $+g$ & - & ND & ND & $\begin{array}{l}\text { Streptococcus } \\
\text { spp. }\end{array}$ \\
\hline 2 & $\begin{array}{l}\text { Entire edge, } \\
\text { Smooth,convex, } \\
\text { yellow } \\
\text { colony }\end{array}$ & Rod & - & $\begin{array}{l}\text { a- Heam- } \\
\text { olysis }\end{array}$ & + & $\mathrm{O} / \mathrm{F}$ & + & $+g$ & $+g$ & $+g$ & $+g$ & $+g$ & $+g$ & $+g$ & - & Mucoid & ND & $\begin{array}{l}\text { Enterobacter } \\
\text { spp. }\end{array}$ \\
\hline $2 \mathrm{C}$ & $\begin{array}{l}\text { Flat,mucoid, } \\
\text { luxuriant, } \\
\text { white colony }\end{array}$ & Rod & + & $\begin{array}{l}\text { B-Heam- } \\
\text { olysis }\end{array}$ & + & $\mathrm{O} / \mathrm{F}$ & + & + & $+g$ & - & +9 & +9 & +9 & $+g$ & - & Mucoid & $\mathrm{ND}$ & $\begin{array}{l}\text { Bacillus } \\
\text { polymyxa }\end{array}$ \\
\hline 5 & $\begin{array}{l}\text { Entire edge, } \\
\text { Smooth,convex, } \\
\text { yellow } \\
\text { colony }\end{array}$ & Rod & + & $\begin{array}{l}\text { B- Heam- } \\
\text { olysis }\end{array}$ & - & $-/ / F$ & + & $+g$ & + & + & - & - & - & - & - & - & $\begin{array}{l}\text { Growth } \\
\text { mannitol } \\
\text { fermented }\end{array}$ & Bacillus spp. \\
\hline 6 & $\begin{array}{l}\text { Entire edge, } \\
\text { Smooth,convex, } \\
\text { white } \\
\text { colony }\end{array}$ & Rod & + & $\begin{array}{l}\text { B-Heam- } \\
\text { olysis }\end{array}$ & + & $\mathrm{O} / \mathrm{F}$ & + & +9 & + & - & + & - & +9 & $+g$ & + & - & $\begin{array}{l}\text { Growth } \\
\text { mannitol } \\
\text { fermented }\end{array}$ & Bacillus spp. \\
\hline $\begin{array}{l}9 \mathrm{MJR}(1 \\
\mathrm{l}^{-}\end{array}$ & $\begin{array}{l}\text { Lobate,Translusce } \\
\text { nt,Mucoid,golden } \\
\text { yellow. }\end{array}$ & $\begin{array}{l}\text { Cocci } \\
\text { in } \\
\text { cluster }\end{array}$ & + & $\begin{array}{l}\text { B- Heam- } \\
\text { olysis }\end{array}$ & + & $\mathrm{O} / \mathrm{F}$ & - & +9 & + & + & - & + & $+g$ & + & + & $\mathrm{ND}$ & $\begin{array}{l}\text { Growth } \\
\text { mannitol } \\
\text { fermented }\end{array}$ & $\begin{array}{l}\text { Micrococcus } \\
\text { spp. }\end{array}$ \\
\hline OGR (1) & $\begin{array}{l}\text { Lobate,Smooth,um } \\
\text { bonate pink colony }\end{array}$ & Rod & & $\begin{array}{l}\text { B- Heam- } \\
\text { olysis }\end{array}$ & + & $\mathrm{O} / \mathrm{F}$ & + & +9 & $+g$ & $+g$ & $+g$ & $+g$ & +9 & +9 & + & Mucoid & & $\begin{array}{l}\text { Klebsiella } \\
\text { spp. }\end{array}$ \\
\hline OGR (2) & $\begin{array}{l}\text { Lobate, rough,raise } \\
\text { d,green to purple } \\
\text { Colony. }\end{array}$ & Rod & - & $\begin{array}{l}\text { B-Heam- } \\
\text { olysis }\end{array}$ & + & $\mathrm{O} /-$ & + & +9 & +9 & + & - & - & +9 & +9 & + & & $\mathrm{ND}$ & $\begin{array}{l}\text { Pseudomonas } \\
\text { aeroginosa }\end{array}$ \\
\hline 10a & $\begin{array}{l}\text { Lobate,,raised,tan } \\
\text { white } \\
\text { Colony. }\end{array}$ & $\begin{array}{l}\text { Cocci } \\
\text { in } \\
\text { cluster }\end{array}$ & & $\begin{array}{l}\text { a-Heam- } \\
\text { olysis }\end{array}$ & & $\mathrm{O} / \mathrm{F}$ & - & + & $+g$ & $+g$ & +9 & +9 & +9 & $+g$ & & & $\begin{array}{l}\text { No } \\
\text { growth }\end{array}$ & $\begin{array}{l}\text { Veillonella } \\
\text { spp. }\end{array}$ \\
\hline $10 / 11$ & $\begin{array}{l}\text { Lobate,raised, } \\
\text { yellow } \\
\text { Colony. }\end{array}$ & Rod & - & $\begin{array}{l}\text { B- Heam- } \\
\text { olysis }\end{array}$ & + & $\mathrm{O} / \mathrm{F}$ & + & $+g$ & + & + & + & + & - & - & - & $\begin{array}{l}\text { Green } \\
\text { metallic } \\
\text { sheen }\end{array}$ & - & $\begin{array}{l}\text { Escherichia } \\
\text { coli }\end{array}$ \\
\hline 15 & $\begin{array}{l}\text { Lobate,,raised,tan } \\
\text { white } \\
\text { Colony. }\end{array}$ & $\begin{array}{l}\text { Large } \\
\text { rod }\end{array}$ & + & $\begin{array}{l}\text { B- Heam- } \\
\text { olysis }\end{array}$ & + & $\mathrm{O} / \mathrm{F}$ & & + & + & + & & + & & & + & & $\begin{array}{l}\text { Growth } \\
\text { mannitol } \\
\text { Not, } \\
\text { fermented }\end{array}$ & $\begin{array}{l}\text { Bacillus } \\
\text { megaterium }\end{array}$ \\
\hline
\end{tabular}


Table 2a:

Distribution pattern of Bacterial isolates cultured from the Lagos Lagoon.

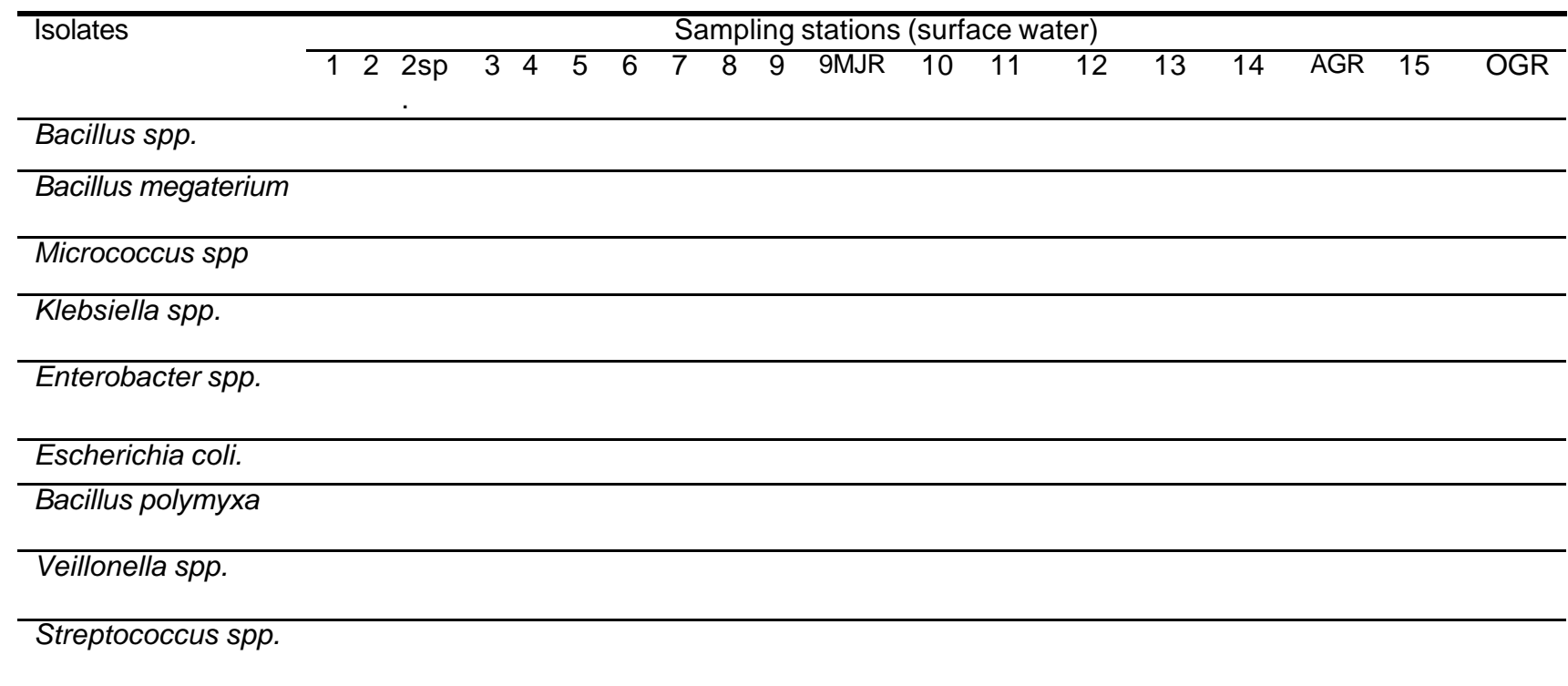

Pseudomonas spp.

Legend: Present: + ; Absent : -

Table 2b:

Distribution Pattern of Enteric Organism in The Lagos Lagoon.

\begin{tabular}{lll}
\hline Stations & February & June \\
\hline & $\begin{array}{l}\text { Coliform Count } \\
\text { Cfu } X 10^{3}\end{array}$ & $\begin{array}{l}\text { Coliform Count } \\
\text { Cfu } X 10^{3}\end{array}$ \\
\hline 1 & 2.5 & 0.21 \\
\hline 2 & 7.1 & 0.35 \\
\hline 2 Special & 2.8 & 0.67 \\
\hline 3 & 0.50 & 2.4 \\
\hline 4 & 0.10 & 1.8 \\
\hline 5 & 0.30 & 0.37 \\
\hline 6 & 0.10 & 0.70 \\
\hline 7 & 0.40 & 0.19 \\
\hline $5 / 7$ & 1.7 & 1.00 \\
\hline $7 / 9$ & 0.48 & 0.37 \\
\hline 8 & 0.50 & 1.10 \\
\hline 9 & 1.5 & 0.80 \\
\hline 10 & 0 & 0.28 \\
\hline 11 & 0.20 & 1.7 \\
\hline 12 & 0 & 1.4 \\
\hline $12 / 10$ & 0.70 & 1.7 \\
\hline $12 / 14$ & 0.40 & 3.2 \\
\hline $9 \mathrm{MJR}$ & 3.0 & 0.50 \\
\hline AGR & 7.0 & 0.20 \\
\hline OGR & 0.30 & - \\
\hline 13 & 0 & 0.80 \\
\hline 14 & 0.20 & 0.60 \\
\hline 15 & 0.30 & 0.15 \\
\hline
\end{tabular}

Legend: N.D - Not Determined
Here the enteric Gram negative rods organisms such as Klebsiella spp. Enterobacter spp. and Escherichia coli were found to be widely distributed in the Lagos Lagoon. The organisms recovered in the Lagoon ranged from a high of 7.1 $X 10^{3} \mathrm{cfu} / \mathrm{ml}$ recorded in station 2 and Agboyi creek respectively to low coliform counts of zero (0) in each of the stations 10,12 and 13 for the month of February. In June, the total coliform count also ranged from a high of $3.2 \times 10^{3} \mathrm{cfu} / \mathrm{ml}$ in station $12 / 14$ to a lows coliform count of 0.15 $\mathrm{X} 10^{3} \mathrm{cfu} / \mathrm{ml}$ observed in station 15 . The individual coliform count varied from station to station. (Table 2).

Each sampled site constituted different type of bacterial species apart from the coliform groups of organism. Table 2 shows that though there were more coliform organisms in February but there were some dominant species in the sampled site. Thus the enteric organisms were encountered in less frequency for February than June when there was more widespread of the enteric organisms in most of the designated station probably due to their dispersal by rainfall and tide. . The enteric organisms identified as Escherichia coli, Enterobacter spp. and Klebsiella spp. were found in many areas of the Lagos Lagoon as shown in Tables 1 and 2. The in vitro antibiotic sensitivity test performed for bacterial isolates revealed that $6(60 \%)$ of the selected strains tested showed multiple antibiotic resistance (Table 3). 
Table 3:

Antibiotic Sensitivity Profile of selected Bacterial strains encountered in the Lagos Lagoon.

\begin{tabular}{|l|l|l|l|l|l|l|l|l|l|l|l|}
\hline $\begin{array}{l}\text { Isolate } \\
\text { Code }\end{array}$ & Bacterial Species & GM & NA & TS & TC & TR & AM & SM & SC & SX & CL \\
\hline 1 & Escherichia coli & $18 \mathrm{R}$ & $15 \mathrm{R}$ & $18 \mathrm{R}$ & $18 \mathrm{R}$ & $17 \mathrm{~S}$ & $0 \mathrm{R}$ & $16 \mathrm{R}$ & $12 \mathrm{R}$ & $0 \mathrm{R}$ & $22 \mathrm{R}$ \\
\hline 2 & Enterobacter spp & $22 \mathrm{~S}$ & $18 \mathrm{R}$ & $25 \mathrm{~S}$ & $22 \mathrm{R}$ & $20 \mathrm{~S}$ & $9 \mathrm{R}$ & $20 \mathrm{~S}$ & $8 \mathrm{R}$ & $0 \mathrm{R}$ & $18 \mathrm{R}$ \\
\hline 5 & Bacillus spp & $28 \mathrm{~S}$ & $25 \mathrm{R}$ & $28 \mathrm{~S}$ & $25 \mathrm{R}$ & $0 \mathrm{R}$ & $40 \mathrm{~S}$ & $15 \mathrm{R}$ & $10 \mathrm{R}$ & $23 \mathrm{~S}$ & $35 \mathrm{~S}$ \\
\hline 6 & Bacillus spp & $26 \mathrm{~S}$ & $30 \mathrm{~S}$ & $40 \mathrm{~S}$ & $36 \mathrm{~S}$ & $24 \mathrm{~S}$ & $35 \mathrm{~S}$ & $16 \mathrm{R}$ & $16 \mathrm{~S}$ & $33 \mathrm{~S}$ & $38 \mathrm{~S}$ \\
\hline $9 \mathrm{MJR}(1)$ & Micrococcus spp. & $26 \mathrm{~S}$ & $32 \mathrm{~S}$ & $38 \mathrm{~S}$ & $38 \mathrm{~S}$ & $25 \mathrm{~S}$ & $28 \mathrm{~S}$ & $24 \mathrm{~S}$ & $16 \mathrm{~S}$ & $22 \mathrm{~S}$ & $31 \mathrm{~S}$ \\
\hline OGR (1) & Klebsiella spp. & $18 \mathrm{R}$ & $17 \mathrm{R}$ & $25 \mathrm{~S}$ & $17 \mathrm{R}$ & $19 \mathrm{~S}$ & $8 \mathrm{R}$ & $22 \mathrm{~S}$ & $14 \mathrm{R}$ & $7 \mathrm{R}$ & $22 \mathrm{R}$ \\
\hline OGR (2) & $\begin{array}{l}\text { Pseudomonas } \\
\text { aeroginosa }\end{array}$ & $26 \mathrm{~S}$ & $40 \mathrm{~S}$ & $36 \mathrm{~S}$ & $24 \mathrm{R}$ & $42 \mathrm{~S}$ & $35 \mathrm{~S}$ & $20 \mathrm{~S}$ & $16 \mathrm{~S}$ & $34 \mathrm{~S}$ & $36 \mathrm{~S}$ \\
\hline $7 / 9$ & Klebsiella spp & $18 \mathrm{R}$ & $17 \mathrm{R}$ & $26 \mathrm{~S}$ & $17 \mathrm{R}$ & $19 \mathrm{~S}$ & $8 \mathrm{R}$ & $22 \mathrm{~S}$ & $14 \mathrm{R}$ & $7 \mathrm{R}$ & $22 \mathrm{R}$ \\
\hline $10 / 11$ & Escherichia coli & $18 \mathrm{R}$ & $15 \mathrm{R}$ & $17 \mathrm{R}$ & $18 \mathrm{R}$ & $17 \mathrm{~S}$ & $0 \mathrm{R}$ & $16 \mathrm{R}$ & $12 \mathrm{R}$ & $7 \mathrm{R}$ & $22 \mathrm{R}$ \\
\hline 15 & Bacillus megatarium & $28 \mathrm{~S}$ & $10 \mathrm{R}$ & $18 \mathrm{R}$ & $28 \mathrm{~S}$ & $0 \mathrm{R}$ & $0 \mathrm{R}$ & $0 \mathrm{R}$ & $13 \mathrm{R}$ & $21 \mathrm{~S}$ & $26 \mathrm{~S}$ \\
\hline
\end{tabular}

Legend:

$S$ - Sensitivity, R-Resistant, GM-Gentamicin, AM - Ampicillin,

SM - Streptomycin, NA - Nalidixic acid, TS - Trimethoprim

+ Sulfamethoxazole , SC-Spectinomycin, TR-Trimethoprim, TC-Tetracycline, SX-Sulfamethoxazole, CL -Chloromphenicol

The presence of this kind of organisms is of epidemiological significance because the multiple antibiotic resistant enteric organisms may be difficult to treat in case of human infections. The site of occurrence of the enteric organisms may help in proper monitoring of the Lagoon for sustainable ecological development.

\section{DISCUSSION}

This study shows that contamination of the Lagoon with coliform bacteria occurred in all the stations that were sampled except one (Table 1\& 2). The study of Akpata and Ekundayo (1978) also confirmed the presence of coliform bacteria relevant areas of the Lagoon. These suggest that the Lagoon is relatively unsafe for swimming and other recreational purposes. It may also indicate that individuals with open sores or skin abrasions may be at the risk of getting infected with these organisms, more so if such individuals are also immunocompromised.

Enteric Gram negative short rods, lactose fermenters, such as klebsiella spp, Enterobacteria spp and Escherichia coli constituted high percentage of the entire organism cultured from the Lagos Lagoon samples suggesting recent contamination of this body of water with human sewage. According to Ajao and Fagade (1990), since the later part of $19^{\text {th }}$ century, the Lagoon has served as the ultimate sink for the disposal of untreated domestic sewage. This may have serious health implications. Various wastes and contaminants discharged into the Lagoon contribute to a large extent to the metabolic activity of microorganisms (UNESCO, 1981;Webb, 1958). Bacillus species are equally widely encountered in the Lagoon. This may be due to inherent nature of this organism which is associated with its ability to survive in hostile environment. The in vitro antibiotic sensitivity profile of the isolates was determined. $6(60 \%)$ of these microorganisms tested showed multiple antibiotic resistance. These include the enteric gram negative short rods such as klebsiella spp., Enterobacter spp., and Escherichia coli (Table 3).

In conclusion, this study shows that the entire organisms found in most areas showed multiple antibiotic resistance which if consumed by marine organisms and humans could spread within food chain. This is significant healthwise and also indicates the prevalence of multiple antibiotic resistant bacterial isolates in our natural water as shown in this study through contamination with human wastes. The results obtained in the study would be helpful to ecologists and health-care administrators in the proper monitoring of our natural waters for proper health care management.

\section{REFERENCES}

Ajao E.A and Fagade S.O (1990). A study of the sediment and communities in Lagos Lagoon, Nigeria, 32pp.

Akpata T.V.I. and Ekundayo, J.A. (1978). Faecal pollution of the Lagos Lagoon. Nig. J. Sc.12 (1 \& 2) Nigeria. 
Baker J.M.(1976). Biological monitoring principles, methods and difficulties.In:Marine Ecology and Oil Pollution. Jenifer M.Baker(ed). Institute of Petroleum, London.pp 47-52

Bauer, A.W., Kirby, W.W.M., Sherrie, J.C. and Turck M. (1966). Antibiotic susceptibility testing by a standardized single disc method. American Journal on clinical pathology 45

Halasi-kun, G.J. (1981). Pollution and water resources, Columbia University seminar series volume XIV part 2. Pollution, coastal biology and water resources selected reports. Pergamon press, New York 10523. U.S.A.

Munn R.E.(1979). Environmental Impact Assessment: Principles and Procedures. SCOPE Report 5 ( $2^{\text {nd }}$ Edition) John Wiley.Chichester, England
Prescott M.L, Harley P.J. and Klein. A.D. (2002). Microbiology. ( $5^{\text {th }}$ Edition). Win C. Brown Publishers.

Robert, A. S., Eller S.H., and Connie, A.N.V. (1984). Introduction to food borne fungi $\left(12^{\text {th }}\right.$ edition) Institute of the Royal Netherlands Academic of Acts and Science. Netherlands.

UNESCO (1981) Coastal Lagoon research, present and future Unesco technical papers in marine science No 32. Report and guidelines of a seminar. Duke University marine Laboratory Beanfort, NC., U.S.A. August 1978 (UNESCO, IABO), U.S.A.

Webb. J.E. (1958). Ecology of Lagos Lagoon III. The life history of Branchiostoma negeriense webb. Phil. Soc. Bulletin; 241:355-91 Nigeria.

\footnotetext{
* Author for correspondence
} 